\title{
Do distinct water chemistry, reservoir age and disturbance make any difference on phosphatase activity?
}

\author{
Ana Maria GERALDES ${ }^{1)}$ and Maria-José BOAVIDA ${ }^{2) *}$ \\ ${ }^{1)}$ Escola Superior Agrária de Bragança, Campus de Santa Apolónia 5301-885 Bragança, Portugal \\ ${ }^{2)}$ Centro de Biologia Ambiental, Departamento de Biologia Animal, Faculdade de Ciências da Universidade de Lisboa, Campo \\ Grande C8, 1749-016 Lisboa, Portugal \\ *e-mail corresponding author: mjboavida@fc.ul.pt
}

\begin{abstract}
Alkaline phosphatase activity was assessed concomitantly with total phosphorus, orthophosphate and phosphomonoester concentrations in two meso-eutrophic reservoirs with distinct age and subjected to different kinds of environmental influence. Differences in conductivity, temperature and $\mathrm{pH}$ were found. However, during the study period alkaline phosphatase activity was similar in both reservoirs. Water colour was higher in S. Serrada Reservoir. This fact can be related to (1) reservoir age (2) high internal disturbance (3) large imputs of allochthonous detritus, resulting from the combined effect of grazing, fire and catchment slope. Despite the high water colour recorded in S. Serrada, alkaline phosphatase activity was apparently not inactivated by humic substances. Besides, the obtained results demonstrated that hydrolysis of phosphomonoesters by alkaline phosphatase was not important for orthophosphate regeneration in these reservoirs. Probably orthophosphate was always available to biota. In fact, in the experiments based on Selenastrum capricornutum Printz algal test, similar phytoplankton growth responses were obtained for different phosphorus concentrations. Thus, these results seem to indicate that phosphorus was not a limiting nutrient in either reservoir. Although phosphatase activity was significantly correlated with some phytoplankton genera in both reservoirs, no significant correlations were found between enzyme activity and chlorophyll-a. Significant correlations between phosphatase activity and crustacean zooplankton were only recorded in S. Serrada. In spite of these results there was some indication that the main source of phosphatase might have been bacteria involved in decomposition processes instead of phyto- and zooplankton taxa.
\end{abstract}

Key-words: Alkaline phosphatase; orthophosphate regeneration; phytoplankton; zooplankton; reservoirs

\section{INTRODUCTION}

Traditionally (Vollenweider 1968), as well as over recent decades (Harper 1992; Wetzel 2001), phosphorus has been clearly identified as the principal nutrient underlying cultural eutrophication of lakes and reservoirs all over the world. Among the several forms of phosphorus, orthophosphate is the only one directly available to biota. Consequently, when managing reservoir trophic state it is of ultimate importance to understand the mechanisms of orthophosphate regeneration by biota and their contribution to the observed concentrations of this chemical form of phosphorus in the water column. One of the mechanisms of orthophosphate regeneration is hydrolysis of complex phosphorus compounds by extracellular alkaline phosphatases. These enzymes are often found as free dissolved enzymes or bound to cell surfaces or membranes and their main sources are bacterioplankton (Jansson et al. 1981; Halemejko \& Chrost 1984; Wynne et al. 1991; Rai \& Jacobsen 1993), phytoplankton (Pettersson 1980; Jansson et al. 1981; Olsson 1983; Boavida \& Heath 1986; Wynne et al. 1991; Spijkerman \& Coesel 1998; Štrojsová et al. 2002) and zooplankton (Boavida \& Heath 1984; Bogé et al. 2002). Phosphomonoesters are the most frequent substrates of phosphatases occurring in fresh waters (Kuenzler \&
Perras 1965). Thus, the concentrations of those compounds are often inversely correlated with phosphatase activity (Heath \& Cooke 1975; Berman 1970; Hashimoto et al. 1985; Boavida \& Heath 1988; Wynne et al. 1991; Feuillade \& Dorioz 1992). According to these authors the level of alkaline phosphatase activity can be taken as an indicator of phosphorus deficiency. However, although many organisms respond with production of phosphatases when orthophosphate availability is low (adaptive production), others continue to produce them independently of orthophosphate concentration in the environment (constitutive production). In addition, phosphatase activity is susceptible of being temporarily inactivated when humic compounds are present in the environment. This phenomenon is a consequence of the formation of complexes between enzyme and the mentioned compounds (Kim \& Wetzel 1993; Boavida \& Wetzel 1998). In this manner, phosphatase is not necessarily an indicator of orthophosphate abundance or deficiency. Jones (1972) also mentioned that phosphatase activity could be used as a measure of lake trophy, but again this is not an universal rule in many systems, since no significant correlation was always found either between enzyme activity and orthophosphate or between phosphatase activity and phosphomonoesters (e.g. Boavida 1991; Boavida \& Marques 1995; Geraldes \& Boavida 1999). Nevertheless, data concerning phos- 

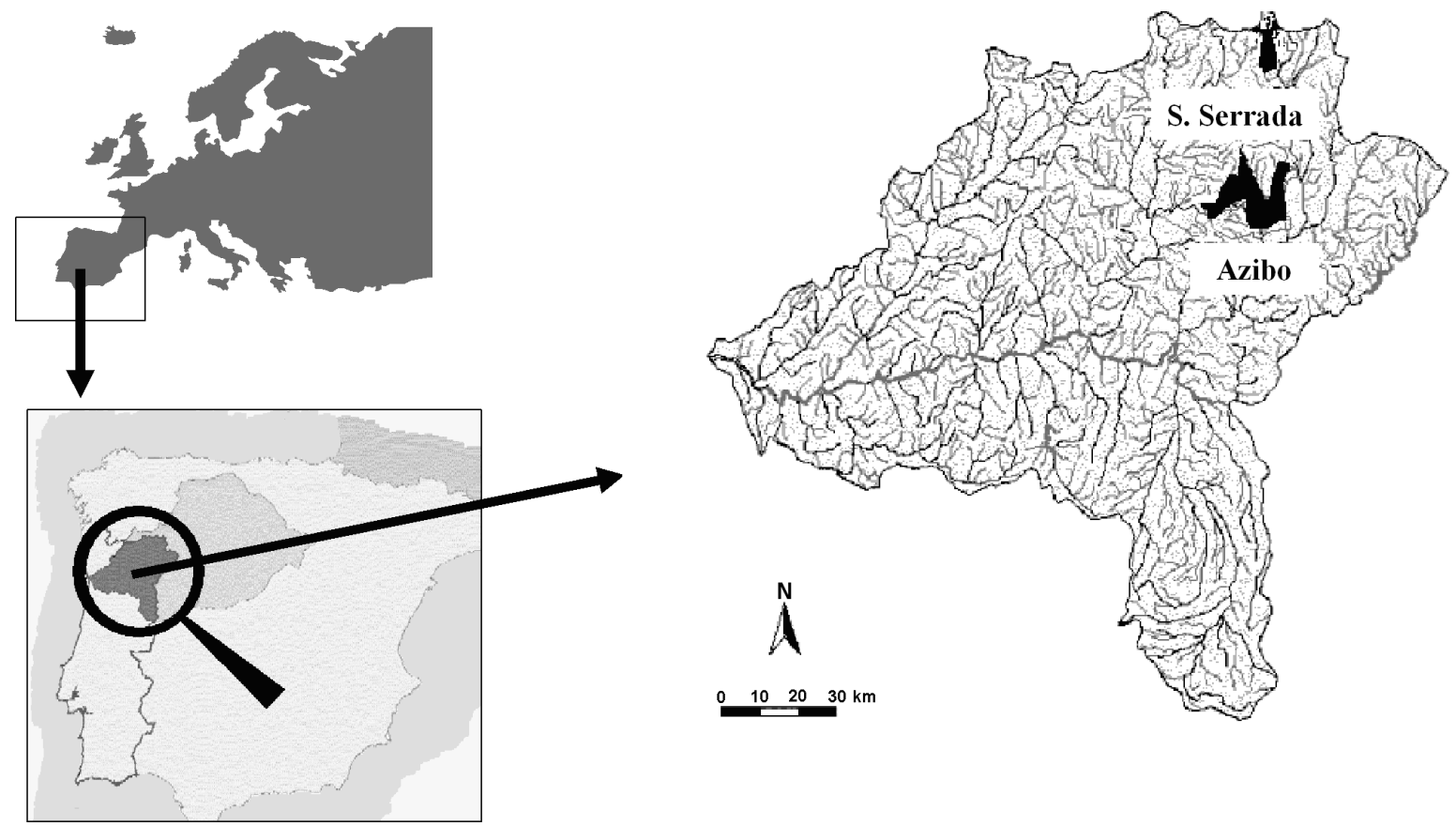

Fig. 1. Location of S. Serrada and Azibo reservoirs in the map of Portugal.

phatase activity, when used with some caution, can be useful indicators of phosphorus recycling and availability.

The present study was conducted form January 2000 to December 2002 in two reservoirs with distinct physical and chemical water features, age and anthropogenic disturbance. Because it was the first time a limnological approach was taken in the study of both reservoirs, the main objectives of this research were: (1) to assess any seasonal differences found in phosphatase activity between reservoirs and relate them to environmental variables such as conductivity, temperature, water colour and $\mathrm{pH}$ (2) to determine the potential importance of enzymatic hydrolysis as an orthophosphate regeneration mechanism; (3) to measure the intensity of association between phosphatase activity and the dominant phytoplankton and crustacean zooplankton taxa.

\section{STUDY AREA}

S. Serrada $\left(41^{\circ} 57^{\prime} \mathrm{N}, 6^{\circ} 46^{\prime} \mathrm{W}\right.$, altitude $\left.1300 \mathrm{~m}\right)$ and Azibo $\left(41^{\circ} 32^{\prime} \mathrm{N}, 6^{\circ} 53^{\prime} \mathrm{W}\right.$, altitude $\left.500 \mathrm{~m}\right)$ reservoirs are located in Portuguese part of River Douro catchment (Fig. 1).

S. Serrada Reservoir is lying on granitic bedrock and the total capacity of the reservoir, spreading over 25 ha, is $1680 \times 10^{3} \mathrm{~m}^{3}$. Maximum depth is $17 \mathrm{~m}$, mean depth is $6.7 \mathrm{~m}$. Direct human influence on S. Serrada impoundment is considered negligible. There are no villages close by, there has been no agricultural activity for approximately 20 years, and recreational activities are not significant. However, grazing can be very intense in the catchment during summer months. Consequently, this area is very often subjected to wild fires often induced by shepherds to obtain better graze. This reser- voir was filled for the first time in 1995 to supply water and hydroelectric power to the city of Bragança. As a result of these uses, accentuated water level fluctuations occur. The annual range of water level variation is between 8 and $10 \mathrm{~m}$. Thermal stratification was observed from June to August/beginning of September. Disruption of stratification was coincidental with the lowest water level. During the period of study this reservoir was classified as meso-eutrophic.

Azibo Reservoir is located on schistic bedrock. The area of the reservoir is 410 ha and its total capacity is $54470 \times 10^{3} \mathrm{~m}^{3}$. Maximum depth is about $30 \mathrm{~m}$, while mean depth is $13.2 \mathrm{~m}$. This reservoir was filled for the first time in 1982 and it is used mainly for recreation. Other uses are water supply and irrigation, yet those are not significant and water level fluctuations are not very accentuated, varying between 1.5 and $2 \mathrm{~m}$. In Azibo direct influence of human activities is greater during summer, when reservoir and surroundings are used for recreation such as swimming, camping, boating and angling. Other activities found all over the year in the catchment area are farming and grazing. During the period of study thermal stratification occurred from June to October and the reservoir was classified as meso-eutrophic. In the region where both reservoirs are located, the climate is continental, with warm, dry summers and long, cold winters. However, because of the influence of Mediterranean climate in the remaining Iberian Peninsula, precipitation occurs mainly in autumn and winter, but in a very irregular regime, with wet winters usually alternating with dry ones. Further information concerning morphological and hydrological characteristics of both reservoirs can be found in Geraldes \& Boavida (2003). 
Tab. 1. Environmental factors recorded for S. Serrada and Azibo reservoirs during the study period. Minimum-maximum range is shown for each factor, with mean/standard deviation below between brackets; (mean/SD).

\begin{tabular}{lccc}
\hline & 2000 & 2001 & 2002 \\
\hline S. Serrada & & & \\
Water temperature $\left({ }^{\circ} \mathrm{C}\right)$ & $1.46-21.39$ & $2.70-20.19$ & $2.79-21.05$ \\
& $(12.51 / 6.59)$ & $(12.90 / 6.46)$ & $(12.37 / 6.06)$ \\
Dissolved oxygen $\left(\mathrm{mg}^{-1}\right)$ & $7.38-12.42$ & $6.20-10.72$ & $7.19-10.40$ \\
& $(8.55 / 1.45)$ & $(8.55 / 1.49)$ & $(8.45 / 1.53)$ \\
Conductivity $\left(\mu \mathrm{S} \mathrm{cm}^{-1}\right)$ & $4-10$ & $3-8$ & $7-12$ \\
& $(6.94 / 1.84)$ & $(5.95 / 1.61)$ & $(8.06-1.53)$ \\
Water transparency $(\mathrm{m})$ & $1.00-4.50$ & $1.00-5.00$ & $1.00-3.00$ \\
& $(2.66 / 1.09)$ & $(2.85 / 1.14)$ & $(2.88 / 0.63)$ \\
Water colour $(\mathrm{T} . \mathrm{A} . \mathrm{units})$ & $0.22-1.02$ & $0.31-0.83$ & $0.41-1.06$ \\
& $(0.52 / 0.25)$ & $(0.54 / 0.16)$ & $(0.62 / 0.20)$ \\
pH & $5.77-6.56$ & $5.95-8.34$ & $6.33-8.77$ \\
Azibo & & & \\
Water temperature $\left({ }^{\circ} \mathrm{C}\right)$ & $5.58-24.70$ & $8.06-23.83$ & $6.08-23.70$ \\
& $(16.52 / 6.13)$ & $(17.16 / 5.73)$ & $(13.31 / 5.80)$ \\
Dissolved oxygen $\left(\mathrm{mg} \mathrm{l}^{-1}\right)$ & $7.54-11.53$ & $7.21-10.78$ & $7.00-10.19$ \\
& $(9.09-1.06)$ & $(8.89 / 1.33)$ & $(8.47 / 1.00)$ \\
Conductivity $\left(\mu \mathrm{S} \mathrm{cm}{ }^{-1}\right)$ & $51-81$ & $43-66$ & $42-76$ \\
& $(69.87 / 11.09)$ & $(56.23 / 7.64)$ & $(61.00 / 10.57)$ \\
Water transparency $(\mathrm{m})$ & $1.50-6.00$ & $1.50-5.50$ & $2.00-9.00$ \\
& $(4.72 / 1.25)$ & $(3.50 / 1.14)$ & $(4.40 / 1.85)$ \\
Water colour $(\mathrm{T} . \mathrm{A}$. units) & $0.21-0.37$ & $0.21-0.59$ & $0.21-0.54$ \\
& $(0.26-0.05)$ & $(0.31 / 0.11)$ & $(0.28 / 0.09)$ \\
pH & $6.71-8.05$ & $6.64-8.36$ & $6.93-8.08$ \\
\hline
\end{tabular}

\section{METHODS}

Samples were collected monthly in winter and biweekly in summer, from January 2000 to December 2002 at one single sampling station, located at the deepest point of each reservoir. Water samples for orthophosphate (determined as soluble reactive phosphorus SRP), total phosphorus (TP), phosphomonoesters (PME), alkaline phosphatase activity (APA), chlorophyll- $a(\mathrm{CHL}-a)$ and water colour measurements were obtained from the upper $30-40 \mathrm{~cm}$ stratum directly into acid rinsed bottles and were transported to the laboratory in a cold container. SRP concentrations were estimated by the method of Murphy and Riley (1962) and TP was assessed after acid hydrolysis with persulfate for 60 min under high temperature and pressure. PME concentrations were determined according to Boavida (1991). APA was measured fluorimetrically, using 4methylumbelliferylphosphate as substrate (Pettersson \& Jansson 1978). CHL a was obtained from 500 to 1000 $\mathrm{ml}$ of water filtered through a Whatman GF/A filter no more than $2 \mathrm{~h}$ after collection. Concentrations were determined spectrophotometrically after overnight extraction in $90 \%$ acetone. Water colour was determined spectrophotometrically at $440 \mathrm{~nm}$, according to Cuthbert \& Del Giorgio (1992), so that it would give a measure of the amount of humic compounds in solution. Environmental factors such as water temperature, dissolved oxygen, conductivity and $\mathrm{pH}$ were measured in situ with a 6820 YSI Multiparameter Water Quality Monitor. Water transparency was measured with a black and white $20 \mathrm{~cm}$ diameter Secchi disk. Zooplankton samples were obtained on each sampling date by taking two vertical hauls (depth range 10 to $15 \mathrm{~m}$, sometimes coincidental with maximum reservoir depth) and using a Wisconsin type net with $64 \mu \mathrm{m}$ mesh size. Animals were anaesthetised with carbonated water and preserved in sugar saturated formaldehyde (4\% final concentration). Depending on density, zooplankton were counted in sub-samples of 5, 10,20 $\mathrm{ml}$ or in the whole sample. Animals were always identified to species. Phytoplankton samples were collected from the upper 30-40 $\mathrm{cm}$ stratum and were fixed in situ in Lugol's solution. Phytoplankton were counted according to Utermöhl (1958), using an inverted microscope at 200X/400X magnification. Algae were identified to genus.

Because of many logistic constraints preventing correct performance of the Selenastrum capricornutum Printz algal assay bottle test (Miller et al. 1978), phosphorus limitation in the reservoirs was investigated seasonally during 2002 by means of a modification of this classical experiment; a fixed volume of a solution spiked with increasing concentrations of phosphorus (050-100-200 $\mathrm{g} \mathrm{I}^{-1} \mathrm{KH}_{2} \mathrm{PO}_{4}$ ) was added to equal volumes of whole reservoir water, expecting a phytoplankton growth response whenever there was P-limitation in the reservoir. CHL- $a$ concentrations were measured at day0 , day-7 and day-14. Phytoplankton growth response was measured as the difference between CHL- $a$ concentrations at day-14 and day-7, and day-7 and day- 0 . Incubation temperature was $21 \pm 2{ }^{\circ} \mathrm{C}$. Illumination was provided by $11 \mathrm{~W}$ Ecotone fluorescent lighting during the whole 24 hours cycle. 

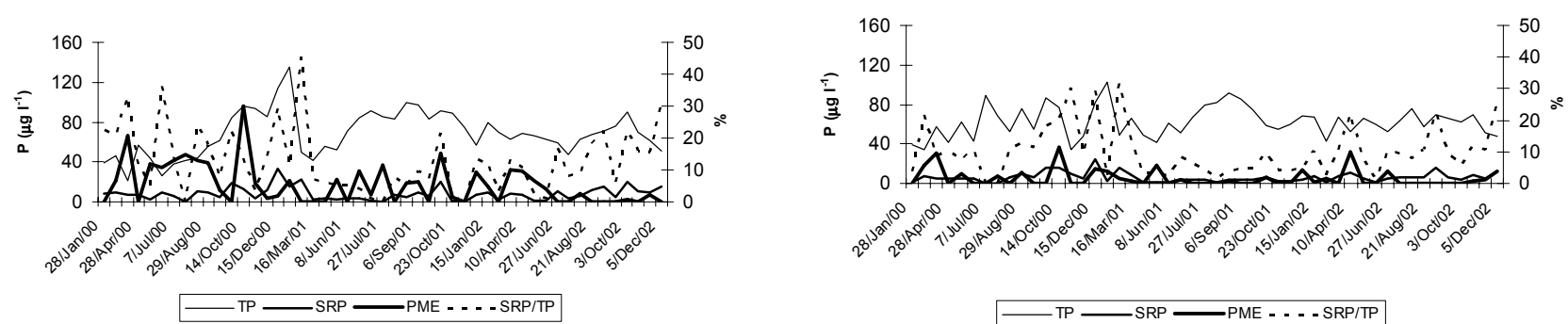

—TP — $-\mathrm{SRP} \longrightarrow \mathrm{PME}-\ldots$ - - SRP/TP
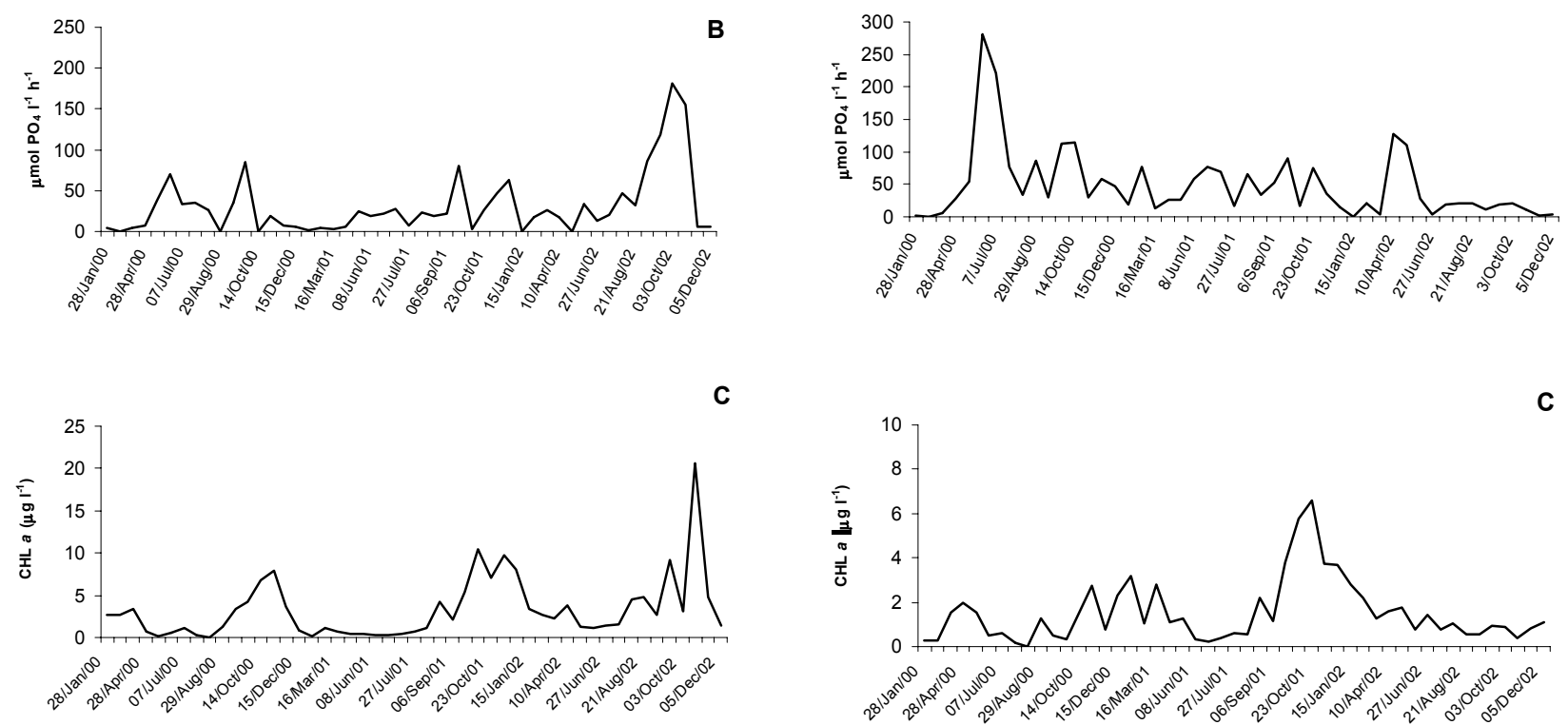

Fig. 2. Trends observed, during this study, in TP, SRP; PME and TP/SRP (A); APA (B) and in CHL- $a(\mathrm{C})$ in S. Serrada.

A Kolmogorov-Smirnov test was performed to assess differences among water chemistry and physical parameters during the study period for both reservoirs. This test is based on the maximum absolute difference $\left(D_{\max }\right)$ between the observed cumulative distribution functions for both samples. When this difference is significantly large, the two distributions are considered different. Correlations among APA, water chemistry parameters, phyto- and zooplankton and CHL- $a$ were determined using the non-parametric Spearman correlation test (Sokal \& Rohlf 1981). All statistical tests were performed using SYSTAT 8.0.

\section{RESULTS}

\subsection{Phosphatase activity and environmental variables}

Dissimilar conductivity $\left(\mathrm{D}_{\max }=1 ; p<0.01\right)$, water temperature $\left(\mathrm{D}_{\max }=0.34 ; p<0.05\right)$, water transparency $\left(\mathrm{D}_{\max }=0.49 ; p<0.01\right), \mathrm{pH}\left(\mathrm{D}_{\max }=0.53 ; p<0.01\right)$ and water colour $\left(\mathrm{D}_{\max }=0.75 ; p<0.01\right)$ were found between reservoirs (Tab. 1). Unlike the physical characteristics, TP and SRP concentrations were similar in both reservoirs. PME $\left(\mathrm{D}_{\max }=0.35 ; p<0.05\right)$ and CHL- $a$ $\left(\mathrm{D}_{\max }=0.31 ; p<0.05\right)$ concentrations were higher in $\mathrm{S}$. Serrada than in Azibo (Figs 2 and 3).

Fig. 3. Trends observed, during this study, in TP, SRP; PME and TP/SRP (A); APA (B) and in CHL- $a(\mathrm{C})$ in Azibo.

In S. Serrada, significant correlations were found between CHL- $a$ and water transparency $(r=-0.74 ; p$ $<0.01)$ and between CHL- $a$ and water level variation $(r$ $=-0.60 ; p<0.01)$. TP was significantly correlated with water transparency and water level variation $(r=0.32 ; p$ $<0.05 ; r=-0.74 ; p<0.01$, respectively). In this reservoir water transparency was inversely correlated with water colour $(r=-0.54 ; p<0.01)$. In Azibo CHL a was inversely correlated with water transparency $(r=-0.54 ; p$ $<0.01)$. Water transparency was inversely correlated with water colour $(r=-0.51 ; p<0.01)$.

In spite of distinct reservoir age and human influence, as well as the different values found for water temperature, conductivity, $\mathrm{pH}$, water colour and transparency, APA was found to be similar in both reservoirs With a few exceptions, APA was low (Figs 2 and 3) in both reservoirs.

In S. Serrada APA was significantly correlated with temperature $(r=0.43 ; p<0.05)$, water colour $(r=0.50$; $p<0.01)$, conductivity $(r=0.50 ; p<0.01)$ and water level variation $(r=-0.35 ; p<0.05)$. In Azibo significant correlations were found among APA and both temperature $(r=0.35 ; p<0.05)$ and conductivity $(r=0.34$; $p<0.05$ ).APA was not significantly correlated with TP, SRP, PME and CHL- $a$ either in S. Serrada or in Azibo. 

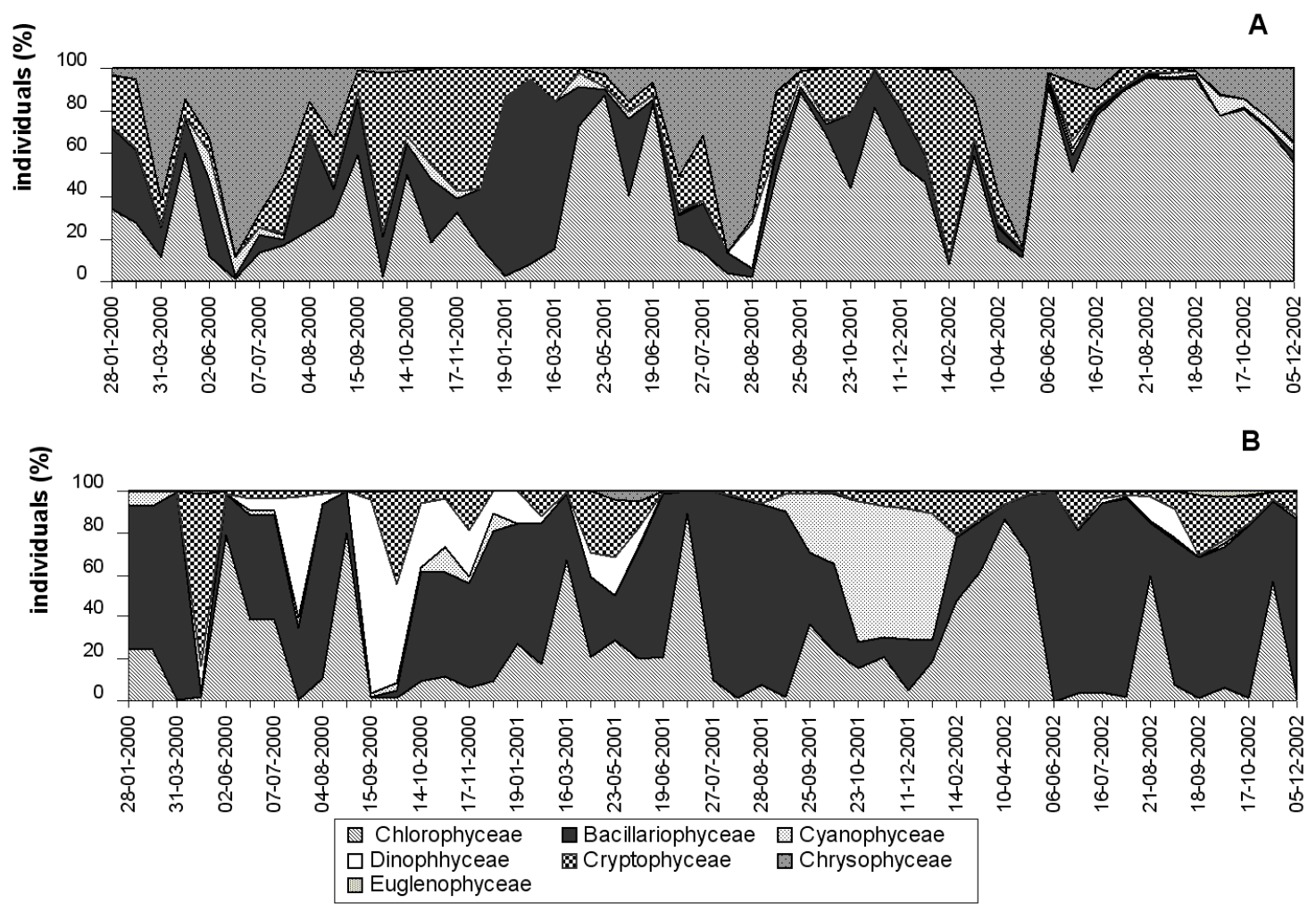

Fig. 4. Relative abundance of the main phytoplankton taxa in S. Serrada (A) and in Azibo (B).
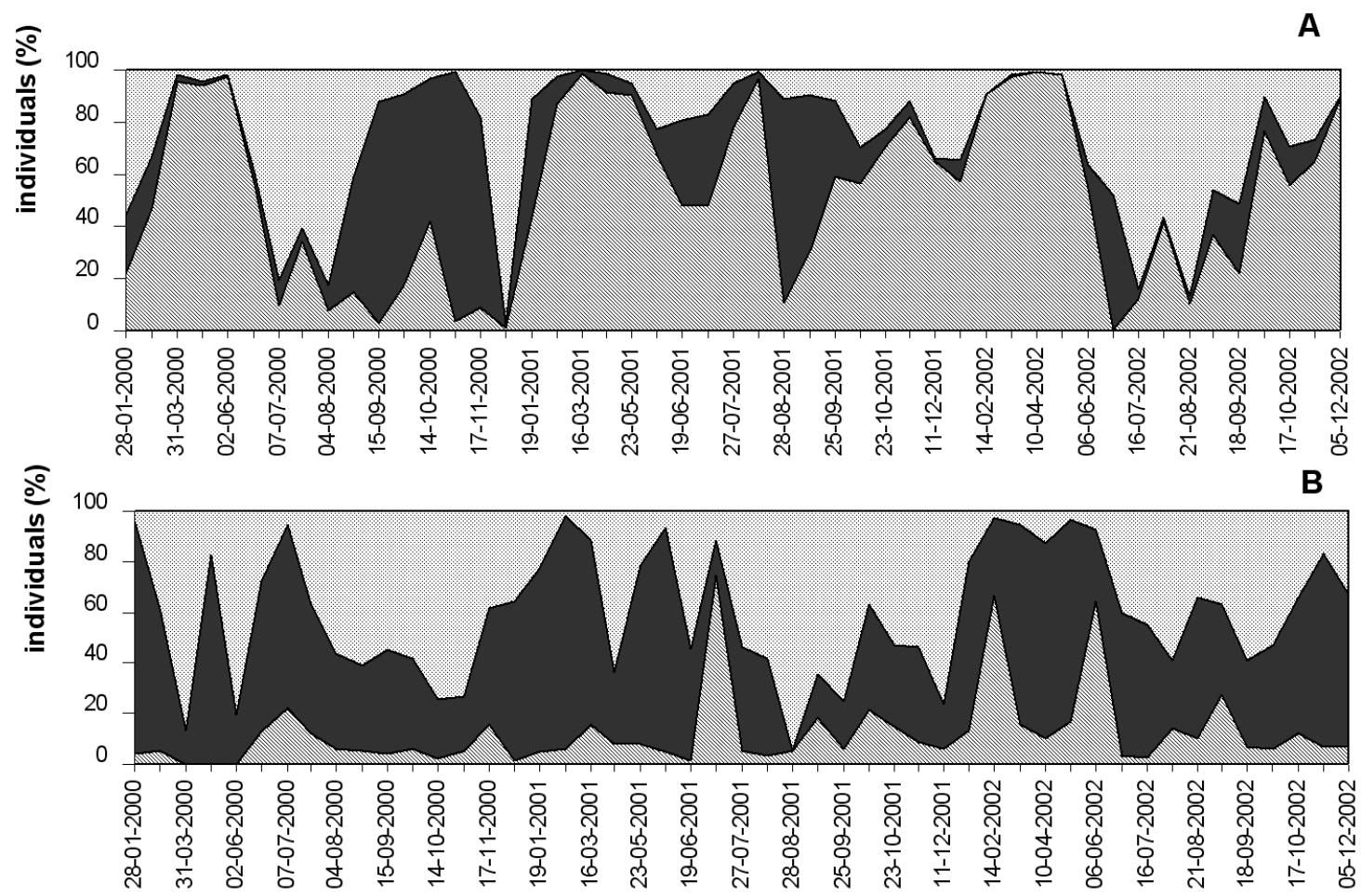

$\mathbb{Q}$ Rotifera $\square$ Copepoda $\square$ Cladocera

Fig. 5. Relative abundance of Rotifera, Copepoda and Cladocera in S. Serrada (A) and in Azibo (B). 


\subsection{Phosphatase activity and phytoplankton abundance}

Chlorophyceae, Bacillariophyceae, Chrysophyceae, Cyanophyceae, Cryptophyceae and Dinophyceae were the most common taxa found in both reservoirs (Fig. 4). In S. Serrada the most representative algae were: (1) Chlorophyceae - Monoraphidium, Dictyosphaerium, Chlamydomonas like cells, Scenedesmus, Crucigenia, Staurastrum and Cosmarium; (2) Bacillariophyceae Tabellaria and Cyclotella; (3) Chrysophyceae - Dinobryon; (4) Cyanophyceae - Anabaena; (5) Cryptophyceae - Cryptomonas; (6) Dinophyceae - Peridinium. In Azibo the most common algae were: (1) Chlorophyceae - Monoraphidium, Chlamydomonas like cells, Scenedesmus, Crucigenia, Tetraedron, Oocystis, Volvox, Paulschulzia and Cosmarium; (2) Bacillariophyceae - Asterionella, Fragilaria and Cyclotella; (3) Chrysophyceae - Dinobryon; (4) Cyanophyceae - Anabaena; (5) Cryptophyceae - Cryptomonas; (6) Dinophyceae - Ceratium. No significant correlations were found between APA and CHL- $a$ in either reservoir. Concerning the relationship between alkaline phosphatase and algal genera, in S. Serrada significant correlations were found among APA and Staurastrum $(r=0.36 ; p<0.05)$, Scenedesmus $(r=0.23 ; p<0.05)$ and Anabaena $(r=$ $0.33 ; p<0.05)$. The only significant correlation for Azibo was found between APA and Ceratium $(r=0.61$; $p<0.01)$.

\subsection{Phosphatase activity and crustacean zooplankton abundance}

In S. Serrada crustacean zooplankton was more abundant during the summer months, whereas in Azibo crustaceans were always dominant over rotifers, except in three sample dates. (Fig. 5). In S. Serrada the taxa dominating crustacean zooplankton were Ceriodaphnia quadrangula and Tropocyclops prasinus. Significant correlations were found among APA and Ceriodaphnia $(r=0.57 ; p<0.01), T$. prasinus $(r=0.30 ; p<0.05)$ and their nauplii $(r=0.49 ; p<0.01)$. In Azibo the most abundant crustacean zooplankton were: Daphnia longispina, Ceriodaphnia pulchella, Bosmina longirostris, Diaphanosoma brachyurum and Copidodiaptomus numidicus. APA was significantly correlated with neither of those.

\subsection{Selenastrum capricornutum type test}

Phytoplankton responded similarly to phosphorus additions in both reservoirs (Figs 6 and 7). It was expected that phytoplankton growth response was proportional to the increasing phosphorus concentrations whenever the nutrient was limiting. However, similar phytoplankton growth responses were obtained for different phosphorus concentrations. Results of these experiments might indicate that phosphorus was not a limiting nutrient in either reservoir.

\section{DISCUSSION AND CONCLUSIONS}

Differences in temperature, $\mathrm{pH}$, conductivity and water colour, as well as in reservoirs' age and human influence, seemed to have had a negligible effect on APA and consequently on orthophosphate regeneration. In fact, the lack of significant inverse correlations between APA and SRP on one hand, and between APA and PME on the other hand, in both reservoirs, demonstrated that the hydrolysis of PME by phosphatases was not an important process in orthophosphate regeneration. Besides, the absence of a significant correlation between SRP and CHL- $a$ might indicate that orthophosphate was not a limiting nutrient for phytoplankton in both reservoirs. In spite of the fact that results of Selenastrum capricornutum type test were not fully conclusive, they seem to corroborate this indication.

Considering the above mentioned facts, three questions arise: (1) if reservoirs seemed not to be P limited why was APA always detected and significantly correlated with Scenedesmus, Staurastrum and Anabaena in S. Serrada and with Ceratium in Azibo? (2) why was APA correlated significantly with Ceriodaphania and $T$. prasinus in S. Serrada? (3) what are the possible origins of the detected phosphatase activity?

In fact, phosphatase can also be produced by algae in a constitutive way independently of orthophosphate concentrations in the water (Berman 1970; Petterson 1980; Boavida \& Heath 1986, 1988). According to Wynne (1981), Wynne et al. (1991) and Cotner \& Wetzel (1992) in many situations extracellular phosphatases may also be involved in metabolic processes not directly connected with $\mathrm{P}$ nutrition such as chloroplast activity and protein synthesis. Consequently, phosphatases are produced even when environmental orthophosphate concentrations are high. It is possible that Scenedesmus, Staurastrum, Anabaena and Ceratium produce phosphatases in a constitutive way. The same explanation can be applied to the significant correlations found between APA and Ceriodaphania/T. prasinus in S. Serrada (e.g. Boavida \& Heath 1984; Bogé et al. 2002). In addition, herbivorous zooplankton can release phosphatases of algal origin ingested with the food (Boavida \& Heath 1984). Moreover, the concomitant increase of those zooplankters densities with APA does not mean that they were the main source of phosphatase; the observed significant correlations between APA and those species could be a matter of coincidence. APA exhibited a tendency to be higher in summer and those populations also peaked in this period, because at the time they might have had better ecological conditions (e.g. temperature, resource supply). On the other hand, no significant correlations where found between APA and CHL- $a$ in either reservoir. This again might indicate that phytoplankton was not the main source of phosphatase or that not all algae were producing the enzyme. 

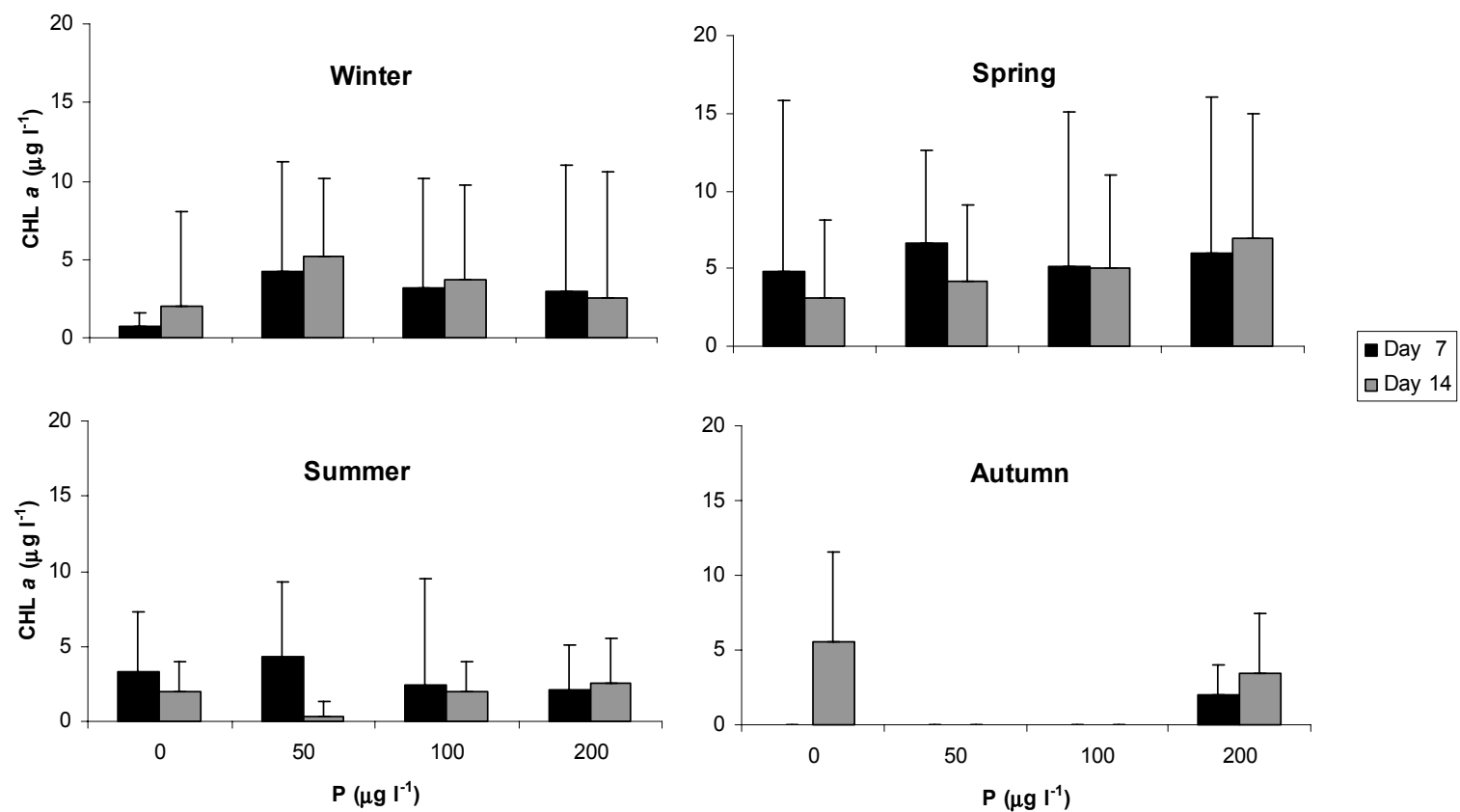

Fig. 6. Results of Selenastrum capricornutum type test in S. Serrada.
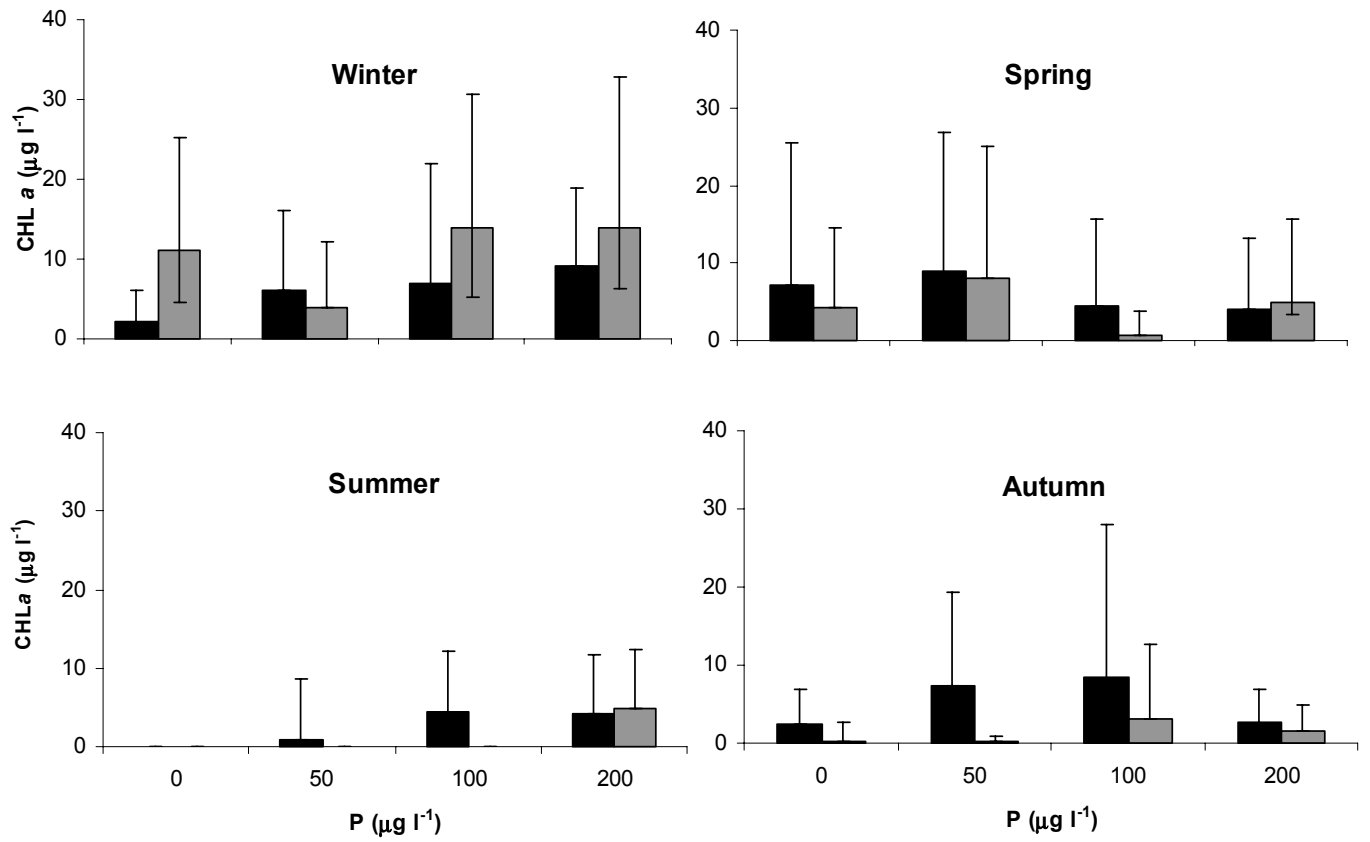

Fig. 7. Results of Selenastrum capricornutum type test in Azibo.

Water colour was higher in summer than in all other seasons in both reservoirs. This parameter is a measure of the concentration of humic compounds in the water (Cuthbert \& Del Giorgio 1992). Humic compounds are products of plant decomposition. Thus, the higher water colour obtained in S. Serrada might indicate the existence of high amounts of products of terrestrial vegetation under decomposition. In fact, the inundated area was previously a permanent meadow and the existing vegetation was not removed before inundation. More- over, the disturbance caused by grazing activity and the frequent fire events seemed to account for appreciable organic matter loading into this reservoir (Geraldes \& Boavida, in press). The turbulence and the atypical disruption of thermal stratification during summer months, generated by water level fluctuations, lead to resuspension, into the water column, of sediments, organic matter and nutrients up until then laying at the bottom (Harper 1992; Gottgens 1994; Wetzel 2001), as well as the associated bacteria (Sherer et al. 1992). Conse- 
quently, phosphatases detected in the water could also have been produced by bacteria. In fact, Marxsen \& Witzel (1991) and Marxen \& Schmidt (1993) detected high phosphatase activity in the surface layers of sediments. Because of logistic constraints no assays on bacterial growth were performed to evaluate whether bacteria were $\mathrm{P}$ limited in the studied reservoirs. However, according to Wetzel (2001), bacterioplankton requirements for phosphorus are four to ten times higher than phytoplankton needs. Thus, bacterioplankton can be $\mathrm{P}$ limited in S. Serrada, and the significant positive correlation between APA and water colour might indicate that APA detected in water column could be related to the resuspension phenomenon. Considering those facts and the lack of correlation between APA and CHL- $a$, it is plausible to think that the main source of phosphatase in S. Serrada were bacteria involved in decomposition processes. Despite of the high water colour observed in this reservoir, it seemed that APA was not inactivated by humic substances present in the reservoir as observed by Kim \& Wetzel (1993) and Boavida \& Wetzel (1998). According to those authors hydrolytic reactivation is possible by exposure to UV irradiance in the upper layer of the photic zone of lakes. In Azibo water colour was lower, indicating that the decaying material existing in the water column was much less than in S. Serrada. This fact can be related to reservoir age (most of the terrestrial vegetation remains might have been already decomposed), to the low degree of internal disturbance (because of the stable water level organic matter was not suddenly resuspended from the bottom) and to the low inputs of allochthonous detritus (those inputs seemed to be higher in S. Serrada as a result of the combined effect of grazing, fire and catchment slope (Geraldes \& Boavida, in press). However, as APA was not correlated either with CHL- $a$ or with zooplankton in Azibo, it is probable that algae and zooplankton were not the main sources of phosphatase. There is some indication that after intense rain events there were high inputs of allochthonous phosphatases. In fact, after a strong rain event APA detected in samples obtained at one Azibo's temporary tributaries was much higher than the activity measured inside the reservoir before the rain (Geraldes, unpubl. data). Pettersson (1980) also described similar results obtained in other lakes. During dry weather APA could be related to bacteria involved in the decomposition of particulate organic matter, and these could be $\mathrm{P}$ limited. Those particles were often present at the water surface, especially during late spring and summer months, and consisted of terrestrial insects and plant fragments of various sizes probably transported by wind from the adjacent land. Some of the plant remains were also fragments of macrophytes existing in the shores of the reservoir. The disturbance caused by recreational activities could also be a source of organic matter influencing APA in this reservoir (Geraldes, pers.obs.).
Contrary to expectations, APA was similar in both reservoirs. Hydrolysis of PME by phosphatase was not important in orthophosphate regeneration. There was also some indication that phytoplankton and zooplankton were not the main source of phosphatase, although some taxa were correlated with APA. It seems that the main producers of phosphatases in both reservoirs might have been bacteria involved in the decomposition processes.

It is apparent from the present results that distinct water chemistry, reservoir age, and disturbance do not make any difference with respect to phosphatase activity in the water. However, the obtained data constitute a preliminary study and might be the basis for further field and experimental research to elucidate these points.

\section{AKNOWLEDGMENTS}

This study was financed by Fundação para a Ciência e a Tecnologia, Portugal (PRAXIS XXI/C/BIA/ 11012/98). AMG was awarded a 4/5.3/PRODEP/2000 Doctoral Fellowship. Assistance of A. Ribeiro, A. Teixeira, N. Marcos, D. Saraiva, S. Branco (in field work) B. Platineti and L. Martín (in lab work) was appreciated. Manuscript revision by D. Ruggiu and an anonymous referee was appreciated as well.

\section{REFERENCES}

Berman, T. 1970. Alkaline phosphatases and phosphorus availability in Lake Kinneret. Limnol.Oceanogr., 25: 663 674.

Boavida, M.J. 1991. Search for phosphomonoesters in Lake Maggiore (N. Italy) during summer. Mem. Ist. ital. Idrobiol., 49:19 27.

Boavida, M.J. \& R.T. Heath. 1984. Are the phosphatases released by Daphnia magna components of its food? Limnol. Oceanogr.,29: 641645.

Boavida, M.J. \& R.T. Heath. 1986. Phosphatase activity of Chlamydomonas acidophila Negoro (Volvocales, Chlorophyceae). Phycologia, 25: 400404.

Boavida, M.J. \& R.T. Heath. 1988. Is alkaline phosphatase always important in phosphate regeneration? Arch. Hydrobiol., 111: 507-518.

Boavida, M.J. \& R.T. Marques. 1995. Low activity of alkaline phosphatase in two eutrophic reservoirs. Hydrobiologia, 297: 11-16.

Boavida, M.J. \& R.G. Wetzel 1998. Inhibition of phosphatase activity by dissolved humic substances and hydrolytic reactivation by natural ultraviolet light. Freshwat. Biol., 40: 285-293.

Bogé, J.L., S. Jamet, R.D. Jamet \& N. Jean. 2002. Contribution of copepods, cladoceran and cirripeds to phosphatase activity in mediterranean zooplankton. Hydrobiologia, 468: 147-154.

Cotner, J.B. \& R.G. Wetzel. 1992. Uptake of dissolved inorganic and organic phosphorus compounds by phytoplankton and bacterioplankton. Limnol. Oceanogr., 37: 232243.

Cuthbert, I.D. \& P. Del Giorgio. 1992. Toward a standard method of measuring color in freshwater. Limnol. Oceanogr., 37: 1319-1326.

Feuillade, M. \& J.M. Dorioz. 1992. Enzymatic release of phosphate in sediments of various origins. Wat. Res., 26: 11951201 . 
Geraldes, A.M \& M.J. Boavida. 1999. Comparioson of a brand new reservoir with a near 40 year old reservoir which has been totally emptied and refilled. Lakes and Reservoirs Management, 4: 15-22.

Geraldes, A.M. \& M.J. Boavida. (2003). Distinct age and landscape influence on two reservoirs under the same climate. Hydrobiologia: (in press).

Gottgens, J.F. 1994.Redistribution of organic sediments in a shallow lake following a short term drawdown. Arch. Hydrobiol., 130: 179-194.

Halemejko, G.R. \& R.J. Chrost. 1984. The role of phosphatases in phosphorus mineralization during decomposition of lake phytoplancton blooms. Arch. Hydrobiol., 101: 489502.

Harper, D. 1992. Eutrophication of freshwaters principles, problems and restoration. Chapman \& Hall, London: 327 pp.

Hashimoto, S.; K. Fujiwara \& K. Fuwa. 1985. Relationship between alkaline phosphatase activity and orthophosphate in the present Tokyo Bay. J. Environ. Sci. Health, 20(7): 781-809.

Heath, R.T. \& G. D. Cooke. 1975. The significance of alkaline phosphatase in a eutrophic lake. Verh. int. Ver. Limnol., 19: $959-965$.

Jones, J.G. 1972. Studies in freshwater microorganisms phosphatase activity in lakes of differing degrees of eutrophication . J. Ecol., 60: 777-791.

Jansson, M., H. Olson \& O. Broberg. 1981. Characterisation of acid phosphatases in the acidified Lake Gardsjön, Sweden. Arch. Hydrobiol., 92: 377-395.

Kim, B. \& R.G. Wetzel. 1993. The effect of humic substances on the alkaline phosphatase and the growth of microalgae. Verh. int. Ver. Limnol., 25: 129132.

Kuenzler, E.J. \& J.P. Perras. 1965. Phosphatases of marine algae. Biol. Bull., 128: 271-284.

Marxsen, J \& K.P. Witzel. 1991. Significance of extracellular enzymes for organic matter degradation and nutrient regeneration in small streams. In: R.J. Chrost (Ed.), Microbial enzymes in aquatic environments. Springer Verlag New York: 270285.

Marxsen, J. \& H.H. Schmidt 1993. Extracellular phosphatase activity in sediments of the Breitenbach, a Central European stream. Hydrobiologia, 253: 207216.

Miller, W.E., J.C. Green \& T. Shiroyama. 1978. The Selenastrum capricornutum Printz algal test assay bottle test:

Received: August 2003

Accepted: October 2003
Experimental design, application and data interpretation protocol. EPA-600/9-78-018: 79 pp.

Murphy, J. \& J. P. Riley 1962. A modified single solution method for the determination of phosphate in natural waters. Anal. Chim. Acta, $27: 3136$.

Olsson, H. 1983. Origin and production of phosphatases in acid lake Garsjön. Hydrobiologia, 101: 49-58.

Pettersson, K. 1980, Alkaline phosphatase activity and algal surplus phosphorus as phosphorus-deficiency indicators in Lake Erken. Arch. Hydrobiol., 89: 54-87.

Pettersson, K. \& M. Jansson. 1978. Determination of phosphatase activity in lake water - a study of methods. Verh. int. Ver. Limnol., 20: 1226-1230.

Rai, H. \& R. Jacobsen. 1993. Dissolved alkaline phosphatase activity (APA) and the contribution of APA by size fractionated plankton in Lake Schöhsee. Verh. int. Ver. Limnol., 25: 164-169.

Sherer, B.M., J.R. Miner, J.A. Moore. \& J.C. Buckhouse 1992. Indicator bacterial survival in sediments. Journal of Environmental Quality, 21: 591595.

Sokal, R.R.\& F.J.Rohlf. 1981. Biometry. W.H. Freeman \& Co., San Francisco: 859 pp.

Spijkekerman, E. \& P.F.M Coesel. 1998. Alkaline phosphatase activity in two planktonic desmid species and the possible role of an extracellular envelope. Freshwat. Biol., 39: 101-111.

Štrojsová, A., J. Komárková, J. Nedoma \& J. Vrba. 2002. Seasonal study of expression of extracellular phosphatases in natural phytoplankton in an eutrophic reservoir. ResLim 2002 (extended abstracts).

Utermöhl, H. 1958. Zur Vervolkommnung der quantitativen Phytoplankton Methodik. Mitt. Int. Verein. Limnol., 9: 1-38.

Vollenweider, R.A. 1968. Scientific fundamentals of the eutrophication of lakes and flowing waters, with particular reference to nitrogen and phosphorus as factors in eutrophication. OECD report DAS/CSI/68.27: $192 \mathrm{pp}$.

Wetzel, R.G. 2001. Limnology - Lake and River Ecosystems. 3rd Edition. Academic Press, San Diego: 1006 pp.

Wynne, D. 1981. The role of phosphatases in the metabolism of Peridinium cinctum, from Lake Kinneret. Hydrobiologia, 83: 93-99.

Wynne, D., B. Kaplan \& T. Berman. 1991. Phosphatase activities in Lake Kinneret phytoplancton. In: R.J.Chrost (Ed.), Microbial enzymes in aquatic environments. Springer Verlag New York: 220226. 